\title{
ENABLING CHARACTERISTIC LSL (LAKI-LAKI SEKS DENGAN LAKI- LAKI) HIV POSITIF DALAM PEMANFAATAN LAYANAN CST (CARE SUPPORT AND TREATMENT) DI KABUPATEN JEMBER
}

\author{
M. Nur Khamid ${ }^{1}$ dan Anisah Prafitralia ${ }^{2}$ \\ Ketua Yayasan Langkah Sehat dan Berkarya (Laskar) Jember ${ }^{1}$ \\ Dosen Prodi BKI Fakultas Dakwah IAIN Jember ${ }^{2}$
}

\begin{abstract}
Abstrak
LSL HIV positif merupakan orang yang melakukan perilaku seks sesama jenis sudah secara positif didiagnosa terinfeksi HIV. Data Dinas Kesehatan Kabupaten Jember dari tahun 2004 sampai Juni 2017 jumlah kasus HIV dan AIDS sebanyak 3.186 kasus, berdasarkan faktor risiko homoseksual sebesar 7,6\%. Tujuan penelitian ini menganalisis Enabling Characteristic kaum LSL HIV positif yang meliputi: a) Penghasilan keluarga/Individu, b) Keikutsertaan asuransi dan biaya, c) Pengetahuan komunitas LSL HIV positif, dan d) Keterampilan petugas kesehatan. Jenis penelitian kualitatif ini menggunakan pendekatan studi kasus. Penentuan Informan menggunakan teknik purposive, dan diperoleh 8 informan dalam penelitian.Data dianalisis dengan metode thematic content analysis (analisis isi berdasarkan tema). Hasil penelitian menunjukkan bahwa sebagian besar pendapatan individu dari informan utama yaitu 3 (tiga) juta per bulan, sebagian kecil informan utama tidak memiliki pekerjaan tetap sehingga penghasilan perbulan tidak menentu, b) Sebagian besar informan utama tidak memiliki jaminan kesehatan, hal ini dikarenakan tidak memiliki KK/KTP serta khawatir status HIV diketahui oleh layanan primer (Puskesmas), c) Informan utama mengetahui informasi layanan VCT (voluntery counseling \& test) dan CST (care support \& treatment) sangat bervariasi yaitu dari petugas kesehatan, media sosial dan media informasi yang dipasang di tempat umum. Sedangkan informan mengetahui jenis ARV (anti retroviral) dari petugas kesehatan dan internet, d)Informan menyatakan bahwa keterampilan petugas kesehatan sudah sangat baik, bahasa yang digunakan oleh petugas halus, ramah, tidak membedakan antar pasien dan petugas.
\end{abstract}

\section{Kata Kunci:LSL, HIV, CST}

\section{Pendahuluan}

Laki-laki Seks dengan Laki-laki (LSL) merupakan orang yang melakukan perilaku seks sesama jenis. HIV (human immunodeficiency virus)merupakan suatu virus yang dapat menyebabkan kekebalan tubuh melemah, yaitu suatu sis- 
tem tubuh yang secara alamiah berfungsi melawan penyakit dan infeksi ${ }^{1}$. LSL HIV Positif merupakan orang yang melakukan perilaku seks sesama jenisyang sudah secara positif didiagnosa terinfeksi HIV.

Pemanfaatan pelayanan kesehatan merupakan suatu hasil dari proses individu maupun kelompok terhadap pencarian pelayanan kesehatan ${ }^{2}$. Enabling Characteristic digunakan untuk menggambarkan pelayanan kesehatan yang dibutuhkan sesuai dengan keadaan dan kondisi dari kemampuan seseorang. Karakterisktik pendukung dalam pelayanan kesehatan akan dipengaruhi oleh kemampuan konsumen untuk membayar, pengetahuan tentang layanan kesehatan, keikutsertaan asuransi dan biaya, keterampilan petugas kesehatan, penghasilan keluarga atau individu. Penggunaan pelayanan kesehatan sematamata terwujud dalam tindakan apabila itu dirasakan sebagai kebutuhan. Perubahan perilaku pada diri seseorang bisa terjadi oleh karena kekuatan pendorong meningkat, motivasi individu untuk berubah, sedangkan kekuatan penahan bisa tetap atau menurun ${ }^{3}$.

KomunitasLSL adalah suatu kelompok atau sub masyarakat yang paling tersembunyi (hidden) sehingga sulit sekali untuk diidentifikasi ${ }^{4}$. Hasil pemetaan GayaNusantara sebuah komunitas khusus LSL di Indonesia memperkirakan 260.000 dari 6.000.000 penduduk Jawa Timur adalah LSL. Prosentase secara Nasional jumlah komunitas LSL mencapai 3\% dari total penduduk Indonesia tahun 2016. Berdasarkan kelompok umur, komunitas LSL ini didominasi pada kelompok umur remaja 5 .Gambaran kehidupan komunitas LSL di Kabupaten Jember berasal dari keterangan LSM Laskar Jember. Berdasarkan data penjangkauan diketahui per Juni 2016 di Kabupaten Jember terdapat kurang lebih 2.030 komunitas LSL 6 . Apabila angka tersebut dibandingkan dengan jumlah total penduduk di Kabupaten Jember, maka keberadaan komunitas LSL saat ini di Kabupaten Jember sebesar 0,81\%.

${ }^{1}$ KPA Nasional. Modul PMTS-LKB-SUFA Populasi Kunci (Jakarta: Publikasi Komisi Penanggulangan AIDS Nasional, 2007). h 10.

${ }^{2}$ Yaslis Ilyas.Asuransi Kesehatan, Review Utilisasi, Manajemen Klaim dan Fraud (Jakarta: Pusat Kajian Ekonomi Kesehatan FKM UI, 2003). h 12.

3Soekidjo Notoatmodjo. Metodologi Penelitian Kesehatan. (Jakarta: PT Rineka Cipta, 2012) h. 11

${ }^{4}$ Dewi Rokhmah. Studi Fenomenologi tentang Homoseksual pada Laki-Laki Seks dengan Laki-Laki di Kabupaten Jember. (Surabaya :DisertasiFakultas Kesehatan Masyarakat Unair, 2016).h 112.

5GWL INA.Laporan Semester Program Penjangkauan LSL. (Jakarta : Laporan GWL INA, 2016).h 23.

6LSM Laskar Kabupaten Jember. Laporan Penjangkauan LSL Program Dukungan IPF PMTS-LKB-SUFA. (Jember : Bidang Pendamping Lapangan Komunitas LSL Khusus ODHA Kabupaten Jember, 2016) h 11 
Angka riil tidak bisa dipastikan karena sebagian besar komunitas LSL masih tertutup (hidden).Tertutupnya komunitas LSL ini dipengaruhi oleh adanya masalah-masalah khusus yang dihadapinya, yaitu prasangka sosial, konflik keluarga, penghinaan dan penolakan rekan sebaya, dan ancaman kesehatan (HIV/AIDS) 7 .Laki-laki yang berhubungan seks dengan laki-laki menjadi terminologi yang populer dalam konteks HIV dan AIDS, karena menggambarkan perilaku yang menempatkan mereka dalam risiko terinfeksi ${ }^{8}$.

Peningkatan prevalensi HIV pada komunitasLSLmenjadi peringatan yang perlu mendapatkan perhatian khusus. Program penanggulangan AIDS pada komunitasLSL selama ini telah menerapkan berbagai metode untuk merubah perilaku yang berisiko tinggi, namun prevalensi HIV pada komunitasLSL tetap saja naik. Laporan dari Kementerian Kesehatan Republik Indonesia menyebutkan bahwa jumlah kumulatif kasus HIV dan AIDS dari awal penemuan kasus pada April 1987 sampai dengan Bulan Maret 2017 sudah terdapat 242.699 kasus. Dari jumlah tersebut kasus AIDS sebanyak 36\%, adapun prosentase berdasarkan jenis kelamin yaitu laki-laki $56 \%$, perempuan $32 \%$ dan $12 \%$ tidak melaporkan jenis kelaminnya. Jumlah infeksi tertinggi yaitu DKI Jakarta 19,3\%, Jawa Timur 13,6\%, Papua 10,5\%, Jawa Barat 10,2\%, Jawa Tengah 7,4\%. Berdasarkan kelompok umur, kasus tertinggi pada kelompok umur 2029 Tahun (31,4\%), kemudian diikuti kelompok umur 30-39 (30,6\%), 40-49 Tahun (12,8\%), 50-59 Tahun (4,6\%) dan 15-19 Tahun (2,7\%). Berdasarkan faktor risiko tertinggi adalah heteroseksual (68\%), Pengguna Narkoba Suntik/Injection Drug Use (IDU)(11\%), dan homoseks (4\%) ${ }^{9}$.

Data Dinas Kesehatan Provinsi Jawa Timur per Juni 2017, Jawa Timur menduduki peringkat ke dua setelah papua dengan total penderita HIV positif sebanyak 42.742 dan AIDS sebanyak 41,5\%. Berdasarkan jenis pekerjaan, urutan tiga tertinggi yaitu wiraswasta $(7,5 \%)$, IRT $(7,4 \%)$ dan tidak menyebutkan jenis pekerjaan (5,5\%). Berdasarkan faktor risiko tertinggi, yaitu heteroseksual (80.19\%), IDU (10,33\%), homoseks (4,42\%), perinatal $(3,79 \%)$ dan biseksual (0,79\%). Berdasarkan kelompok umur tertinggi pada kelompok umur25-29 tahun (8,8\%), 30-34 tahun (8,6\%), 35-39 tahun (6,4\%), 40-44 tahun $(4,9 \%), 20-24$ tahun $(3,4 \%), 45-49$ tahun $(3,2 \%), 50-54$ tahun (2\%), 55-59 tahun

7Gibson, R.L \& Mitchell, M.H. Bimbingan dan Konseling. (Yogyakarta: Pustaka Pelajar, 2011).H 260.

${ }^{8}$ Dewi Rokhmah. . Studi Fenomenologi tentang Homoseksual pada Laki-Laki Seks dengan Laki-Laki di Kabupaten Jember. (Surabaya :DisertasiFakultas Kesehatan Masyarakat Unair, 2016).h 98.

${ }^{9}$ Kementerian Kesehatan RI.Situasi HIV/AIDS di Indonesia. (Jakarta : Kementerian Kesehatan RI, 2017).h 30. 
(1\%), 0-4 tahun (1\%), lebih dari 60 tahun (0,7\%), 14-19 tahun (0,5\%), dan 5-9 tahun $(0,3 \%)^{10}$.

Data Dinas Kesehatan Kabupaten Jember dari tahun 2004 sampai Juni 2017 jumlah kasus HIV dan AIDS sebanyak 3.186 kasus. Berdasakan faktor risiko tertinggi heteroseksual $(86,8 \%)$, homoseksual $(7,6 \%)$, perinatal $(2,5 \%)$, IDU $(1,8 \%)$, waria $(1 \%)$, biseksual $(0,06 \%)$ dan transfusi darah $(0,1 \%)$. Sedangkan jika dilihat dari jenis pekerjaan urutan tiga tertinggi yaitu IRT $(24 \%)$, wiraswasta $(21,8 \%)$ dan penjaja seks $(10,7 \%)$. Berdasarkan kelompok umur tertinggi adalah 25-49 tahun (70,7\%), 20-24 tahun (13\%), lebih dari 50 tahun (6,9\%), 15-19 tahun (2,6\%), dan 0-4 tahun $(2,1 \%)^{11}$.

Program penanggulangan AIDS yang dilakukan di Kabupaten Jember oleh Komisi Penanggulangan AIDS Daerah (KPAD) Kabupaten Jember, LSM dan Dinas Kesehatan Kabupaten Jember meliputi: Komunikasi perubahan perilaku (KPP), Pemakaian kondom 100\% di daerah berisiko, Layanan klinis infeksi menular seksual (IMS), Program Pengurangan Dampak Buruk (harm reduction) Penggunaan Narkoba Suntik, Konseling dan testing sukarela (KTS atau VCT). Program-program tersebut merupakan program pencegahan sekaligus jembatan untuk mengakses layanan manajemen kasus (MK) dan CST (Care, Support, and Treatment) bagi ODHAdi Rumah Sakit Daerah Dr. Soebandi, Rumah Sakit Daerah Balung dan tiga Puskesmas Satelit ARV (Puskesmas Kencong, Puskesmas Tanggul dan Puskesmas Sumberjambe). Program CST merupakan layanan terpadu dan berkesinambungan untuk mengurangi atau menyelesaikan permasalahan yang dihadapi ODHA, baik bagi aspek medis, psikologis maupun sosial ${ }^{12}$.

Hasil studi pendahuluan di poli CST Rumah Sakit dr. Soebandi Kabupaten Jember, terdapat 142 LSL HIV positif masuk perawatan HIV. 57,8 \% dari total tesebut on ART (sedang mengikuti anti retroviral therapy), 13,2 \% meninggal, $25 \% \mathrm{LFU}$ (lost to follow up / berhenti menjalani terapi di tengah jalan), $4 \% \mathrm{di}$ rujuk ke luar. Kondisi ini menggambarkan bahwa perilaku komunitas LSL HIV positif di Kabupaten Jember terhadap pemanfaatan layanan CST sangat rendah. Penyebab LFU pada komunitas LSL HIV positif diantaranya pindah tempat, sekolah, dan pindah bekerja.Komunitas LSL HIV positif lebih memilih pengobatan tradisional dan supranatural dibandingkan pengobatan ARV, tidak percaya dengan pengobatan ARV. Komunitas LSL HIV positif ini

10Dinas Kesehatan Propinsi Jawa Timur. Analisis Situasi HIV di Propinsi Jawa Timur. (Surabaya :Bidang Pencegahan Penyakit dan Kesehatan Lingkungan, 2017).h 19.

11Dinas Kesehatan Kabupaten Jember. Pemetaan Kasus HIV/AIDS. (Jember :Bidang Pencegahan Penyakit dan Kesehatan Lingkungan, 2017). h 17.

12ibid 
biasanya cenderung mencari informasi sendiri diluar penjelasan petugas CST, tidak memiliki biaya cukup untuk pengobatan ARV.Stigma dan diskriminasi komunitas LSL HIV positif ini masih sangat kuat pada komunitas LSL itu sendiri dan masyarakat ${ }^{13}$.

Hasil penelitian Krisna (2011) menyatakan bahwa usia muda lebih mudah untuk LFU karena mereka sering berpindah tempat kerja ataupun memiliki kesibukan sekolah ${ }^{14}$. Hasil penelitian Rosiana (2014) menyatakan ada hubungan erat antara jenis kelamin dengan perilaku pemanfaatan layanan CST, dimana laki-laki berisiko tinggi untuk mengalami LFU dikarenakan tidak percaya dengan kondisi, memiliki kesibukan dan mencari informasi diluar penjelasan petugas VCT terutama pada komunitas LSL ${ }^{15}$. Penelitian Yudi (2016) menyatakan bahwa LFU pada laki-laki lebih tinggi terutama pada kelompok LSL ${ }^{16}$.

\section{Pembahasan}

\section{Penghasilan Keluarga/individu}

Hasil penelitian menyatakan bahwa terdapat hubungan antara pendapatan keluarga dengan pemanfaatan layanan kesehatan. Pada keluarga yang memiliki pendapatan diatas rata-rata,mereka akan cenderung menggunakan layanan kesehatan lebih banyak. Secara materi mereka akan mengeluarkan biaya lebih banyak dibandingkan keluarga yang memiliki pendapatan rendah ${ }^{17}$. Berdasarkan hasil wawancara dengan informan utama, sebagian besar pendapatan keluarga adalah 3 (tiga) juta per bulan, sebagian kecil pendapatan keluarga 5 (lima) juta dan terdapat 1 (satu) informan utama menyatakan tidak tahu tentang pendapatan keluarga karena tidak pernah bertanya kepada orang tua.

13Dinas Kesehatan Kabupaten Jember. Pemetaan Kasus HIV/AIDS. (Jember :Bidang Pencegahan Penyakit dan Kesehatan Lingkungan, 2017). h 18.

${ }^{14}$ Krisna S. Incidence Rate of and Factors Assosiated with Loss to Follow up in A Longitudinal Cohort of Anti-retroviral Treated HIV-Infected Person: an AIDS Clinical Trials Group (ACTG) Longitudinal Linked Randomized Trials (ALLRT) Analysis. (Jurnal Kesehatan. Vol.5 Juli 2011).

${ }^{15}$ Alifa NasyahtaRosiana.Faktor-Faktor yang Mempengaruhi loss to follow up pada Pasien HIV dengan Terapi ARV di Rumah Sakit dr. Kariadi Semarang.Semarang :Jurnal Media Medika MudaUniversitas Diponegoro, 2014). h 5

${ }^{16}$ Yudhi Tri Gunawan. Hubungan Karakteristik ODHA dengan Kejadian Loss to Follow up Terapi ARV di Kabupaten Jember. (Jurnal Kesehatan Masyarakat. Vol. 12. 1 Maret 2016).

${ }^{17}$ Andersen R. \& J.F. Newman. Societal and Individual Determinants of Medical Care Utilizationin the United State. (The Milbank Quarterly,Vol. 83 No. 4, 2005). 
Komunitas LSL HIV positif yang sudah bekerja tentunya memiliki pendapatan sendiri guna untuk memenuhi kebutuhan pribadi serta keluarganya. Berdasarkan wawancara mendalam dengan informan utama, diketahui sebagian besar informan utama sudah bekerja dengan penghasilan per bulan 3 (tiga) juta, sebagian kecil informan utama tidak memiliki pekerjaan tetap sehingga penghasilan perbulan tidak menentu dan 2 (dua) informan utama memiliki penghasilan dibawah 1 (satu) juta per bulan. Hasil penelitian Yeni, dkk. menunjukkan adanya hubungan antara penghasilan keluarga dengan pemanfaatan layanan kesehatan. Semakin tinggi pendapatan keluarga, pemanfaatan layanan kesehatan semakin baik ${ }^{18}$.

\section{Keikutsertaan Asurasi Kesehatan dan Biaya}

Biaya atau tarif berkaitan erat dengan permintaan pelayanan kesehatan yang dibutuhkan seseorang. Semakin mahal tarif layanan kesehatan maka akan mengakibatkan permintaan layanan kesehatan menurun, serta hubungan tarif dengan permintaan memiliki arah negatif. Perlu diketahui bahwa hubungan tarif dengan permintaan memiliki arah negatif dikarenakan permintaan layanan kesehatan sangat bervariasi menyesuaikan kebutuhan dari setiap individu. Pemanfaatan layanan kesehatan juga dipengaruhi oleh jaminan dan asuransi kesehatan.Kedua hal tersebut sangat berpengaruh positif terhadap permintaan layanan kesehatan. Seseorang yang memiliki jaminan kesehatan atau asuransi kesehatan maka mereka cenderung akan menggunakan layanan kesehatan sesuai dengan kebutuhan mereka. Jika seseorang mengalami sakit makaakan segera melakukan pencarian pengobatan ${ }^{19}$.

Kepemilikan jaminan kesehatan pada komunitas LSL HIV positif sangat membantu komunitas tersebut ketika mengalami drop dan membutuhkan perawatan yang lebih lanjut, sehingga bagi komunitas LSL HIV positif yang memiliki jaminan kesehatan maka tidak perlu mengeluarkan uang lebih untuk kebutuhan perawatan ketika timbul ancama sakit atau sakit. Sistem Jaminan Sosial Nasional (SJSN) secara kebijakan, tidak melakukan diskriminasi pada ODHA. Setiap ODHA berhak mendapatkan akses jaminan pembiayaan ini ${ }^{20}$. Kepemilikan jaminan kesehatan masih menjadi masalah tersendiri pada ko-

${ }^{18 Y e n i, ~ T ., ~ I n a ~ D e b o r a, ~ R ., L . ~ R a f a e l, ~ P . ~ P e m a n f a a t a n ~ V o l u n t a r y ~ C o u n s e l i n g ~ a n d ~ T e s t i n g ~}$ oleh Ibu Rumah Tangga Terinfeksi Human Immunodeficiency Virus. (Jurnal Kesehatan Masyarakat 11 (2), 2016).

${ }^{19}$ Andersen R. \& J.F. Newman. Societal and Individual Determinants of Medical Care Utilizationin the United State. (The Milbank Quarterly,Vol. 83 No. 4, 2005).

${ }^{20}$ Anonim. ODHA dan Jaminan Kesehatan Nasional (serial online).(http://www.odhaberhaksehat.org/2014/odha-dan-jaminan-kesehatan nasional/.(4 Mei 2017)). 
munitas LSL HIV positif dan masyarakat karena tidak semua masyarakat dan komunitas LSL HIV positif memiliki jaminan kesehatan. Permasalahan yang dialami tidak memiliki jaminan kesehatan salah satunya proses pembuatan yang dianggap rumit, tidak memiliki KK (Kartu Keluagra), tidak memiliki KTP (Kartu Tanda Penduduk) dan tidak memiliki biaya cukup untuk membayar iuran per bulan sesuai dengan kelas yang ditentukan. ${ }^{21}$

Berdasarkan hasil wawancara dengan informan utama, sebagian besar informan utama tidak memiliki jaminan kesehatan, hal ini dikarenakan asumsi pembuatan kartu jaminan kesehatan sangat rumit, tidak memiliki KK dan KTP, tidak mempunyai biaya lebih untuk membayar iuran/tarif per bulan sesuai dengan kelas yang ditentukan oleh Badan Penyelenggaran Jaminan Sosial (BPJS). Alasan lain terdapat 1 (satu) informan utama menyatakan bahwa tidak memiliki jaminan kesehatan karena takut status HIV diketahui oleh layanan primer (Puskesmas), mengingat syarat berobat ke rumah sakit meggunakan BPJS harus meminta surat rujukan dari fasilitas kesehatan tingkat pertama (Puskesmas) yang ditunjuk, sehingga ketika komunitas LSL HIV positif membutuhkan biaya untuk pengobatan memilih menggunakan dana mandiri. Terdapat 1 (satu) informan utama yang memiliki akses karena orang tua dari informan utama berstatus Pegawai Negeri Sipil (PNS) dan 1 (satu) Informan Utama memiliki jaminan kesehatan non PBI (bukan penerima bantuan iuran) artinya informan utama membayar iuran per bulan sesuai dengan tarif kelas yang dipilih. Terdapat faktor yang menghambat keikutsertaan jaminan kesehatan, salah satunya adalah ketidaklengkapan administrasi kependudukan ${ }^{22}$.

\section{Keterampilan Petugas Kesehatan dan Jumlah Layanan CST}

Jumlah pelayanan kesehatan sangat mempengaruhi permintaan pelayanan kesehatan.Semakin sedikit pelayanan kesehatan maka permintaan pelayanan kesehatan rendah ${ }^{23}$. Jumlah sumber daya manusia kesehatan serta kompetensi yang dimiliki pada petugas kesehatan sangat mempengaruhi utilitas pelayanan kesehatan. Jumlah sumber daya yang terbatas,mengakibatkan pelayanan kesehatan kurang optimal sehingga masyarakat enggan datang ke layanan kesehatan $^{24}$. Keterampilan petugas kesehatan juga menjadi penentu masyara-

21 ibid

${ }^{22}$ Nopiyani, N. M.S., Indrayathi, P. A., Listyowati, R., Suarjana, I. K., Januraga, P. Akses Jaminan Kesehatan Nasional pada Pekerja Seks Perempuan. (Jurnal Kesehatan Masyarakat Nasional. 9 (4), 2014).h308-314.

${ }^{23}$ Andersen R. \& J.F. Newman. Societal and Individual Determinants of Medical Care Utilizationin the United State. (The Milbank Quarterly,Vol. 83 No. 4, 2005).

24Bustami. 2011. Penjaminan Mutu Pelayanan Kesehatan dan Akseptabilitasnya. (Jakarta : Erlangga, 2011). h 101 
kat untuk akses pengobatan, keterampilan ini meliputi pelayanan pengobatan, penanganan pasien serta bahasa yang digunakan untuk berkomunikasi dengan pasien ${ }^{25}$. Berdasarkan hasil wawancara mendalam dengan informan utama, seluruh informan utama menyatakan bahwa keterampilan petugas kesehatan sudah sangat baik. Sesuai yang diungkapkan oleh informan sebagai berikut:

"Ketrampilan sudah bagus mas, melayani pasien cuka cepat dan gak canggung, ramah juga, mereka itu menganggap kita seperti orang biasa, tidak mengganggap kita sebagai odha, kita dianggap seperti keluarga"(IU 1, 9 Januari 2018).

Bahasa digunakan berdasarkan kebutuhan seseorang, yakni sebagai alat untuk mengekspresikan diri, sebagai alat untuk berkomunikasi, sebagai alat untuk mengadakan integrasi dan adaptasi sosial dalam lingkungan atau situasi tertentu dan sebagai alat untuk melalukan kontrol social. Komunikasi yang tidak tepat dan tidak sesuai dengan kebutuhan komunitas LSL HIV positif dapat menjadi penyebab munculnya gap antara petugas kesehatan dan komunitas LSL HIV positif.Begitu pula sebaliknya, jika bahasa yang digunakan dalam pelayanan kesehatan baik dan sesuai dengan kebutuhan komunitas LSL HIV positif, maka dapat menumbuhkan rasa kenyamanan sehingga komunitas LSL HIV positif dapat menjamin keberlangsungan pengobatan pada komunitas LSL HIV positif ${ }^{26}$.

Berdasarkan hasil wawancara dengan informan utama, seluruh informan utama menyatakan bahasa yang digunakan oleh petugas kesehatan dalam melayani pasien cukup baik, bahasa yang digunakan oleh petugas halus, ramah, tidak membedakan antar pasien dan petugas sering mengajak bercanda komunitas LSL HIV positif saat mengambil obat di layanan CST dengan tujuan untuk menjalin keakraban antar komunitas LSL HIV positif dengan petugas kesehatan. Hasil penelitian Sukmahmenyatakan adanya hubungan baik antara pasien dengan tenaga kesehatan pemberi layanan meskipun ada sebagian yang mengatakan adanya tenaga kesehatan yang kurang ramah atau galak ${ }^{27}$. Sesuai ungkapan informan utama sebagai berikut:

${ }^{25}$ Yaslis Ilyas.Asuransi Kesehatan, Review Utilisasi, Manajemen Klaim dan Fraud (Jakarta: Pusat Kajian Ekonomi Kesehatan FKM UI, 2003), h 56.

${ }^{26 E l i n d a, ~ R ., ~ M u h a m m a d, ~ A . ~ F a k t o r-F a k t o r ~ y a n g ~ B e r h u b u n g a n ~ d e n g a n ~ K e t e r a t u r a n ~}$ Kunjungan Layanan Care Suport and Teratment (CST) pada Pasien Koinfeksi TB-HIV di Balai Kesehatan Paru Wilayah Semarang. (Semarang :Jurnal Ilmu Kesehatan Fakultas Keolahragaan Universitas Negeri Semarang, 2 (1), 2017).h105-110.

27Sukmah, Mahyudin, Suarnanti. Faktor-faktor yang Berhubungan dengan Kepatuhan Berobat pada Pasien TB Paru di RSUD Daya Makassar. (Semarang : Jurnal Universitas Negeri Semarang Vol. 2 Nomor 5, 2013). 
"Enak kok mas, ramah-ramah, malah kalau manggil anak-anak seumuran ku manggilnya kak gitu, jadi bisa lebih akrab mas"(IU 2, 10 Januari 2018).

"Kalau bahasa komunikasi enak mas, tidak ada rasa perbedaan mas, sama dengan penyakit yang lain"(IU 8, 20 Januari 2018).

Sarana berkaitan dengan penampilan fisik fasilitas kesehatan. Kenyamanan, kebersihan, kerapihan, kelengkapan alat periksa, dan ragam obat yang diberikan merupakan faktor penting untuk menarik pasien yang dapat menjamin kelangsungan berobat. Sarana prasarana merupakan unsur lain yang dianggap mempengaruhi pemanfaatan pelayanan kesehatan karena dapat mempengaruhi lama waktu tunggu dalam menerima pelayanan kesehatan yang diinginkan ${ }^{28}$. Dengan adanya sarana prasarana waktu tunggu akan terasa lebih menyenangkan. Kenyamanan merupakan salah satu dimensi mutu yang dapat mempengaruhi kepuasan pasien untuk mau datang memperoleh pelayanan kesehatan berikutnya ${ }^{29}$. Berdasarkan hasil wawancara dengan informan utama, seluruh informan utama menyatakan pelayanan di poli CST Rumah sakit dr. Soebandi sudah baik, waktu tunggu tidak lama tergantung jumlah kunjungan pasien pada hari tersebut.Selain itu lama waktu tunggu mengambil obat tergantung dari pengetahuan pasien mengetahui alur layanan atau tidak. Sesuai ungkapan dari informan utama sebagia berikut:

"Gak sih, kalau nunggu lama gak juga, yang penting kita tau langkah-langkah mau ambil obat, kalau kita gak tahu ya bisa lama mas, apalagi lantai 2 ya kalau riwa -riwi juga capek, yang penting tau alur nya mas, cepet kok heheh"(IU 1, 9 Januari 2018).

Pengobatan HIV pada komunitas LSL HIV positif telah diatur dalam Permenkes No 87 Tahun 2014 tentang Pedoman Pengobatan ARV. Salah satu syarat menjadi konselor HIV yaitu telah mengikuti pelatihan konselor HIV, sehingga dengan mengikuti pelatihan konselor maka harapannya konselor dapat menangani komunitas LSL HIV positif dengan baik sesuai Standar Pelayanan Minumum (SPM) ${ }^{30}$. Konselor HIV harus memahami bahwa pasien HIV positif biasanya kehilangan dukungan dari keluarga dan temannya, yang akan menghilangkan kemampuannya mengatasi masalah, rasa frustasi dan

28Supartiningsih. Kualitas Pelayanan dan Kepuasan Pasien Rumah Sakit: Kasus pada Pasien Rawat Jalan.(Jurnal Mediceoticolegal dan Managemen Rumah Sakit, 6 (1), 2017). h 9-15.

${ }^{29}$ Bustami. 2011. Penjaminan Mutu Pelayanan Kesehatan dan Akseptabilitasnya. (Jakarta : Erlangga, 2011).h 27.

${ }^{30}$ Kementerian Kesehatan RI.Situasi HIV/AIDS di Indonesia. (Jakarta : Kementerian Kesehatan RI, 2017).h 55. 
mengarah kepada depresi serius. Bantuan yang diberikan oleh konselor HIV diharapkan mampu meningkatkan kualitas hidup mereka melalui pengembangan kemampuan pasien mengatasi masalah, membantunya menghadapi dunia kerja dan kembali hidup di masyarakat dengan baik ${ }^{31}$.

Penanganan konselor maupun petugas kesehatan terhadap komunitas LSL HIV sudah cukup baik, terutama pada komunitas LSL HIV positif yang sedang mengalami depresi maupun kondisi kesehatan sedang menurun. Berdasarkan hasil wawancara dengan informan utama, sebagian besar informan utama menyatakan bahwa penanganan terhadap komunitas LSL HIV positif sudah baik, konselor memberikan dukungan dan saran yang membangun serta memberikan solusi sesuai dengan kebutuhan komunitas LSL HIV positif. Sesuai yang diungkapkan informan utama sebagai beirkut:

"Kalau konselor sudah maksimal mas, ya sih aku pernah kaya putus asa gitu mas, 4 hari saya bolak balik rumah sakit, malah petugas ngasih dukungan, saya di suruh sabar, dan tetap semangat mas dan saranya membangun"(IU 2, 10 Januari 2018).

Sebagian kecil informan utama menyatakan bahwa penanganan konselor terhadap komunitas LSL HIV positif yang sedang mengalami drop atau kondisi kesehatan menurun kurang maksimal, hal ini dikarenakan penjelasan dari konselor kurang detail, tidak ada perhatian dari petugas, kurang komunikatif serta jawaban yang diberikan konselor tidak sesuai dengan keinginan dari komunitas LSL HIV positif. Sesuai dengan ungkapan informan utama sebagai berikut:

"Menurut ku konseling nya kurang maksimal mas, untuk penjelasanya kurang nyaman aja mas, gak nyamanya itu jawabanya kadang gak sama dengan keinginan kita, sudah detail sih penjelasanya tapi kadang gak seperti yang tak inginkan mas"(IU 6, 10 Januari 2018).

"Ada petugas yang gak welcome mas, saya merasa kita yang butuh mas, petugas nya cuek mas, kurang komunikatif mas, hanya di resepi terus ambil obat"(IU 7, 20 Januari 2018).

Layanan CST adalah bagian hilir dari program penanggulangan HIV dan AIDS. CST adalah singkatan dari Care, Support and Treatment for PLWHA, dalam bahasa Indonesia adalah Perawatan, Dukungan dan Pengobatan bagi

${ }^{31}$ Gibson, R.L \& Mitchell, M.H. Bimbingan dan Konseling. (Yogyakarta: Pustaka Pelajar, 2011).h260. 
ODHA $^{32}$. Layanan CST yang ada di Kabupaten Jember sampai dengan tahun 2017 berjumlah 5 tempat yaitu 2 (dua) Rumah Sakit: Rumah Sakit dr. Soebandi, Rumah Sakit Balung, dan 3 Puskesmas (Kencong, Tanggul dan Sumberjambe). Jumlah sumber daya manusia layanan CST telah di atur dalam permenkes No 87 Tahun 2014 diantaranya terdapat konselor, dokter CST, petugas RR (Report and Recording), perawat pelaksanan, Manager Kasus (MK), dan konsulen yaitu dokter spesialis penyakit dalam dan spesialis anak. Hasil penelitian Yuniar, dkk (2017) menyatakan tingkat pengetahuan yang tinggi biasanya lebih patuh dalam mejalani pengobatan ${ }^{33}$. Rajin berobat dan mematuhi aturan ditentukan oleh pengetahuan yang baik ${ }^{34}$. Pengetahuan komunitas LSL HIV positif terhadap jumlah layanan CST dan sumber daya manusia yang ada di layanan CST sangat rendah. Berdasarkan hasil wawancara informan utama, sebagian besar informan utama tidak mengetahui jumlah keseluruhan layanan CST yang ada di Kabupaten Jember, informan utama hanya mengetahui layanan CST lain yaitu Rumah Sakit Balung, serta tidak menegtahui jumlah sumber daya manusia yang ada di layanan CST secara pasti dan tidak tugas dan fungsi dari masing-masing petugas yang ada di layanan CST yang dimanfaatkan oleh komunitas LSL HIV positif. Sesuai dengan ungkapan informan utama sebagia berikut:

"Tau mas, ada di Rumah Sakit Soebandi dan Rumah Sakit Balung mas, kalau di soebandi yang sering tak lihat ada 4 orang, dokter nya 1 dan ada 2 cewek dan 1 cowok yang biasa di depan komputer mas"(IU 3, 15 Januari 2018).

Ketersediaan layanan CST yang mencukupi, jumlah layanan CST yang tersedia menjadi pendukung untuk komunitas LSL HIV positif berkunjung pengobatan ARV, semakin banyak layanan CST yang maka semakin banyak komunitas LSL HIV positif akan melakukan pengobatan karena jarak layanan CST dengan tempat tinggal terjangkau, sarana pelayanan yang rapi, bersih begitu pula sebaliknya ${ }^{35}$. Berdasarkan hasil wawancara dengan informan utama

${ }^{32}$ Kementerian Kesehatan RI.Situasi HIV/AIDS di Indonesia. (Jakarta : Kementerian Kesehatan RI, 2017).h 45.

33 Isma Yuniar, Sarwono, Sri Astuti. Pengaruh PMO dan Dukungan Keluarga Terhadap Tingkat Kepatuhan Minum Obat TB Paru di Puskesmas Sempor 1 Kebumen. (Magelang :Proceeding $6^{\text {th }}$ University Research Colloqium 2017 : Seri MIPA dan Kesehatan, 2017). h 20.

${ }^{34}$ Nawas. Keberhasilan Pengobatan TB Paru dan Faktor yang Mempengaruhinya.(J Respi Indo, 2003). h 19.

${ }^{35}$ Rumenang, D., Umboh, J., Kandon., G. Faktor-Faktor yang Berhuungandengan Pemanfaatan Peayanan Kesehatan pada Peserta BPJS Kesehatan di Puskesmas Paniki Bawah Kecamatan Mapengat Kota Manado. (JIKM, 2015). h 5. 
menyatakan bahwa layanan CST di Kabupaten Jember sangat kurang, hal ini dikarenakan kondisi georgrafis Kabupaten Jember yang sangat luas, kasus HIV semakin meningkat, dan jarak yang jauh antara layanan CST.Sesuai diungkapkan oleh informan utama sebagai berikut:

"Menurut saya kurang mas, karena Jember luas, kita gak tau kondisi/kesibukan masing-masing pasien, misal yang bekerja. Seharusnya ada layanan lain mas disesuaikan dengan kondisi Kabupaten Jember"(IU 1, 9 Januari 2018).

Sebagian kecil informan utama menyatakan jumlah layanan CST yang ada di Kabupaten Jember sudah cukup, hal ini dikarenakan akses pengobatan layanan CST tergantung kesadaran dari komunitas LSL HIV positif itu sendiri dan jadwal pengambilan obat komunitas LSL HIV positif tidak bersamaan. Sesuai ungkapan dari informan utama sebagai berikut:

"Kalau menurut ku sudah cukup sih mas, soalnya proses pengambilan obat kan beda-beda, ngambilnya kan bertahap mas, gak langsung barengan"(IU 2, 10 Januari 2018).

"Sudah cukup mas, tergantung dari orang nya mas, mau berobat atau gak. Walaupun pelayanan nya banyak tapi kalau teman-teman LSL susah tes ya sama aja mas"(IU 4, 15 Januari 2018).

Berdasarkan penjelasan diatas dapat disimpulkan bawah ketrampilan petugas kesehatan sudah sangat baik, bahasa yang digunakan oleh petugas halus, ramah, tidak membedakan antar pasien dan petugas sering mengajak bercanda komunitas LSL HIV dengan tujuan untuk menjalin keakraban antar komunitas LSL HIV positif dengan petugas kesehatan. Waktu tunggu tidak lama tergantung jumlah kunjungan pasien pada hari tersebut. Penanganan terhadap komunitas LSL HIV positif sudah baik, konselor memberikan dukungan dan saran yang membangun, dan memberikan solusi sesuai dengan kebutuhan komunitas LSL HIV positif. Sebagian kecil informan menyatakan penjelasan dari konselor kurang detail, tidak ada perhatian dari petugas, kurang komunikatif serta jawaban yang diberikan konselor tidak sesuai dengan keinginan dari komunitas LSL HIV positif. Jumlah layanan CST di Kabupaten Jember sangat kurang, hal ini di karenakan kondisi georgrafis Kabupaten Jember yang sangat luas, kasus HIV semakin meningkat, dan jarak yang jauh antara layanan CST.

\section{Pengetahuan Komunitas LSL HIVPositif tentang Layanan CST (Care Support and Treatment).}

Pengetahuan komunitas LSL HIV positif ini merupakan hasil dari pembe- 
lajaran yang diterima menggunakan panca indra meliputi pendengaran, rasa, penglihatan dan penciuman. Faktor seseorang menjadi tahu ini didominasi oleh penglihatan dan pendengaran ${ }^{36}$. Pengetahuan komunitas LSL terhadap layanan CST berpengaruh terhadap permintaan layanan kesehatan. LSL yang memiliki pengetahuan baik akan cenderung sadar akan kesehatannya ${ }^{37}$. Dalam Peraturan Menteri Kesehatan Nomor 87 Tahun 2014 disebutkan, ARV berguna untuk mengurangi risiko penularan HIV, menghambat perburukan infeksi oportunistik, meningkatkan kualitas hidup penderita HIV, dan menurunkan jumlah virus (viral load) dalam darah sampai tidak terdeteksi. Dari sudut pengetahuan, komunitas LSL ini lebih baik dibandingkan dengan populasi berisiko yang lain seperti (Wanita Penjaja Seks dan Waria). ART bertujuan untuk meningkatkan kualitas hidup ODHA dengan cara menekan replikasi dan meningkatkan jumlah CD4 pada tubuh penderita ${ }^{38}$. Berdasarkan hasil informan utama, seluruh informan utama mengetahui tujuan dari pengobatan ARV yaitu untuk mengunci dan melemahkan virus dalam tubuh komunitas LSL HIV positif, hal ini sesuai dengan yang diungkapkan oleh informan utama sebagai berikut:

"Menjaga untuk odha tetap sehat mas, virus tidak menyebar, saya gak mudah sakit mas, menekan virus dalam tubuh kita supaya gak menyebar ke seluruh tubuh"(IU 4, 15 Januari 2018).

"Ya setau saya biar menjaga kekebalan tubuh, mengunci virus HIV, manfaatnya agar virusnya gak agresif, biar gak terus menggrogoti tubuh, gak begitu cepat jatuh sakit mas"(IU 5, 17 Januari 2018).

Hasil penelitian Lestari (2012) menyatakan bahwa faktor-faktor yang mempengaruhi LSL untuk melakukan tes HIV secara sukarela (VCT), meliputi: pengetahuan terhadap informasi dasar HIV dan AIDS serta layanan VCT ${ }^{39}$. Penelitian Rosiana (2014) menyatakan komunitas LSL cenderung mencari in-

36Soekidjo Notoatmodjo. Metodologi Penelitian Kesehatan. (Jakarta: PT Rineka Cipta, 2012) h. 11.

37Rokhmah, D. Pengetahuan dan Sikap ODHA (Orang HIV dan AIDS) tentang HIV dan AIDS dan Pencegahanya. (Jurnal Ilmu Kesehatan Masyarakat, Vol 9. No.2, 2013).h136-146.

${ }^{38}$ Fletcher, C.V., dan Kakuda, T.N.Human Immunodeficiency Virus Infection. (New York: McGraw-Hill, 2005). h 220.

${ }^{39}$ Heni Eka Puji Lestari, Zahroh Shaluhiyah, Argyo Demartoto. Pengaruh Pengetahuan dan Perceived Behavior Control terhadap Niat Laki-laki yang Berhubungan Seks dengan Laki-laki (LSL) untuk Melakukan VCT di Kabupaten Madiun. (Jurnal Promosi Kesehatan Indonesia Vol. 10 No.1, 2015) 
formasi diluar penjelasan petugas $\mathrm{VCT}^{40}$. Bedasarkan hasil wawancara dengan informan utama menyatakan bahwa, pengetahuan informan utama pertama kali mengetahui layanan VCT dan CST sangat bervariasi diantaranya: 2 (dua) informan utama mengetahui layanan VCT dan CST dari petugas kesehatan, 2 (dua) informan utama mengetahui teman sesama LSL, 3 (tiga) informan utama mengetahui dari facebook dan 1 (satu) informan utama menetahui layanan VCT dan CST dari spanduk yang dipasangan di perempatan jalan. Hal ini diperkuat oleh informan tambahan bahwa sebagian besar komunitas LSL mengetahui layanan VCT dan pengobatan ARV dari searching di internet. sesuai yang di ungkapkan oleh informan tambahan sebagai berikut:

"Biasa mencari informasi sendiri tentang ARV, cari-cari di internet"(IT 37 Th, 23 Januari 2018).

"Bisa dari petugas, browsing"(IT 33 Th, 24 Januari 2018).

Pengetahuan merupakan bagian penting dalam pembentukan perilaku, perilaku yang didasari pengetahuan akan lebih langgeng daripada perilaku yang tidak didasari oleh pengetahuan ${ }^{41}$.Gambaran pengetahuan komunitas LSL tentang jenis ARV berdasarkan hasil wawancara dengan informan utama, sebagian besar informan tidak mengetahui jenis obat ARV yang di konsumsi. Penyebabnya adalah seluruh informan utama tidak mengetahui secara detail jenis-jenis ARV walaupun sudah pernah di jelaskan oleh tenaga kesehatan. Informan utama hanya mengetahui bentuk dari obat yang di konsumsi setiap hari. Tingkat pengetahuan yang tinggi tentang HIV dan AIDS sangat penting bagi komunitas LSL HIV positif untuk mencegah penularan dan melaksanakan pengobatan $\mathrm{ARV}^{42}$ (Rokhmah, 2013). Sesuai ungkapan dari informan utama sebagia berikut:

"Kalau secara detail saya lupa mas, tapi petugas menjelaskan, aku yang lupa mas nama-namanya apa hehehehe"(IU 4, 15 Januari 2018).

Terdapat 1 (satu) informan utama mengetahui jenis ARV yang di konsumsi setiap hari dari internet dari internet/searching. Petugas kesehatan hanya menjelaskan sebagian kecil dari kegunaan ARV serta efek samping

${ }^{40}$ Alifa NasyahtaRosiana.Faktor-Faktor yang Mempengaruhi loss to follow up pada Pasien HIV dengan Terapi ARV di Rumah Sakit dr. Kariadi Semarang.Semarang :Jurnal Media Medika MudaUniversitas Diponegoro, 2014).h 4.

${ }^{41}$ Soekidjo Notoatmodjo.Promosi Kesehatan dan Ilmu Perilaku. (Jakarta: Rineka Cipta, 2010).h 77.

42 Dewi Rokhmah. Pengetahuan dan Sikap ODHA (Orang HIV dan AIDS) tentang HIV dan AIDS dan Pencegahanya. (Jurnal Ilmu Kesehatan Masyarakat, Vol 9. No.2, 2013).h : 136-146. 
ARV. Sesuai yang diungkap oleh informan utama sebagai berikut:

"Dari serching mas, kan obat antar pasien itu berbeda-beda gak sama mas hehee kalau efek ARV dijelaskan mas, yang ngasih tau malah petugas apotik nya kalau di poli ya diperiksa, di kasih buku obat,"kalau konselingnya malah petugas apotiknya mas, bagaimana mencegah biar efek samping gak terlalu besar"(IU 2, 10 Januari 2018).

Pelayanan CST bagi komunitas LSL HIV positif mengacu pada pedoman pengobatan ARV bagi odha dan disesuaikan dengan Permenkes No 87 Tahun 2014, sehingga tidak hanya untuk pengobatan ARV saja, akan tetapi terdapat beberapa layanan penunjang pemeriksaan kesehatan untuk komunitas LSL HIV positif seperti: layanan konseling, pemeriksaan CD4 (mengetahui jumlah kekebalan tubuh), pemeriksaan VCT, konseling gizi, pemeriksaan darah lengkap, layanan PPIA (Program Pencegahan Ibu ke Anak), rontgent, penanganan efek samping, pemantauan pra-ARV dan rawat inap bagi komunitas LSL HIV positif. Hasil observasi yang telah dilakukan oleh peneliti, terdapat layanan CST sesuai dengan Permenkes No 87 Tahun 2014 tentang pedoman pengobatan HIV, akan tetapi khusus untuk pemeriksaan viraload masih kerjasama dengan Dinas Kesehatan Jawa Timur karena layanan CST di Kabupaten Jember belum memiliki alat pemeriksaan viraload. Hal ini diperkuat dengan pernyataan informan tambahan sebagia berikut:

"Ada CD4, PPIA, PITC, konseling, ARV, thorax paru, EID dan viraload. Khusus pemeriksaan EID dan Viraload masih kirim ke Surabaya. Untuk layanan rawat inap ada juga, jd pasien yang kiranya butuh rawat inap, biasanya ada perintah dokter untuk rawat inap dan gabung dengan rawat inap pasien lain"(IT 33 Th, 24 Januari 2018).

Pengetahuan komunitas LSL HIV positif tentang jenis layanan yang tersedia sangat rendah. Kurangnya pengetahuan dan sikap tentang HIV dan AIDS dikarenakan mereka belum mengakses layanan tersebut ${ }^{43}$. Hasil wawancara mendalam dengan informan utama, sebagian besar komunitas LSL HIV positif hanya mengetahui beberapa dari jenis layanan CST yang tersedia seperti layanan cek darah, pemeriksaan CD4, rontgent dan konsultasi kesehatan. Sesuai yang diungkapkan oleh informan utama adalah sebagai berikut:

43 Dewi Rokhmah. Pengetahuan dan Sikap ODHA (Orang HIV dan AIDS) tentang HIV dan AIDS dan Pencegahanya. (Jurnal Ilmu Kesehatan Masyarakat, Vol 9. No.2, 2013).h 136-146. 
"Ada layanan konsultasi mas, bisa tes tau kekebalan tubuh, cek darah mas, untuk mengetahui apa yang bermasalah"(IU 3, 15 Januari 2018).

Yang saya tau cuma ambil obat, pemeriksaan cek darah, CD4, rontgent mas sama konseling aja"(IU 8, 20 Januari 2018).

Sebagian kecil informan utama hanya mengetahui jenis layanan CST untuk pengobatan ARV dan tes HIV saja. hasil wawancara mendalam dengan informan utama menyatakan bahwa orang yang berkunjung ke layanan CST pasti memiliki tujuan yaitu mengambil obat ARV ataupun tes HIV. Sesuai yang diungkapkan oleh informan utama sebagai berikut:

"Yang saya tau hanya VCT dan ambil obat ARV mas, pasti yang datang kesitu kalau gak ambil obat ya tes VCT, kan itu juga rujukan dari PuskesmasPuskesmas, pikirku orang yang ke poli itu pasti ambil obat mas, tapi ya gak tau juga, tapi kalau misal di lihat dari orang nya ya iya sih ngambil obat"(IU 2, 10 Januari 2018).

Hasil penelitian Krisna (2011) menyatakan bahwa usia muda lebih mudah untuk loss to follow-up karena mereka sering berpindah bekerja ataupun memiliki kesibukan sekolah ${ }^{44}$. Penyebab LFU (Loss to Follow-up) pada komunitas LSL HIV positif ini yaitu pindah tempat, sekolah, pindah bekerja, komunitas LSL HIV positif lebih memilih pengobatan tradisional, supranatural dibandingkan pengobatan ARV, tidak percaya dengan pengobatan ARV, biasanya komunitas LSL HIV positif ini cenderung mencari informasi sendiri diluar penjelasan petugas CST, tidak memliliki biaya cukup untuk pengobatan ARV, stigma dan diskriminasi komunitas LSL HIV positif ini masih sangat kuat pada komunitas LSL itu sendiri dan masyarakat. LSL HIV positif juga takut dengan efek samping ARV serta terdapat perilaku negatif bahwa jika belum muncul gejala maka mereka enggan untuk akses pengobatan ${ }^{45}$.

Hasil penelitian Sugiharti (2014)faktor yang meyebabkan pasien ODHA putus obat adalah rasa bosan dan jenuh minum obat, efek samping obat, stigma masyarakat dan biaya pengobatan ${ }^{46}$. Sejalan dengan Alifa (2014) salah satu

${ }^{44}$ Krisna S. Incidence Rate of and Factors Assosiated with Loss to Follow up in A Longitudinal Cohort of Anti-retroviral Treated HIV-Infected Person: an AIDS Clinical Trials Group (ACTG) Longitudinal Linked Randomized Trials (ALLRT) Analysis. (Jurnal Kesehatan. Vol.5 Juli 2011).h 7.

${ }^{45} Y u d h i$ TriGunawan. Hubungan Karakteristik ODHA dengan Kejadian Loss to Follow up Terapi ARV di Kabupaten Jember. (Jurnal Kesehatan Masyarakat. Vol. 12. 1 Maret 2016).

46Sugiharti. Pemanfaatan Layanan Kesehatan pada Perempuan HIV dan AIDS. (Jurnal Kesehatan Masyarakat Vol. 8 No. 1, 2014). 
faktor yang menyebabkan ODHA mengalami Loss to Follow up adalah adanya efek samping dari ARV ${ }^{47}$. Berdasarkan hasil wawancara mendalam dengan infoman utama, sebagian besar informan utama bependapat faktor yang paling dominan komunitas LSL HIV positif putus obat adalah jenuh, rasa bosan, capek minum obat besar-besar, harus minum obat diwaktu dan jam yang sama, efek samping dari obat dan malas. Sesuai yang diungkapkan oleh informan utama sebagai berikut:

"Jenuh mas, yang pertama minum obat seumur hidup, harus tepat waktu, karena kondisi seseorang kan sibuk kerja kadang lupa. Selain itu juga capek mas minum obat, capek juga dengan efek samping dulu mas"(IU 1, 9 Januari 2018).

"Yang pertama sibuk mas, sibuk kerja, males tiap hari yang diminum obat ini terus dan ukuranya besar-besar, bosen, tiap hari harus minum obat di jam yang sama mas. Jadi yang mau minum itu gimana gitu, kalau bisa obatnya sirup mas, saya itu susah minum obat"(IU 5, 17 Januari 2018).

Terdapat 2 (dua) informan utama yang sudah menikah menyatakan pendapat bahwa faktor yang paling dominan untuk komunitas LSL HIV positif putus obat adalah tidak ada motivasi dan kesadaran komunitas LSL HIV positif untuk pengobatan serta tidak terbuka dengan keluarga, teman sehingga berisiko untuk putus obat. Sesuai ungkapan informan utama sebagai berikut:

"Tidak ada motivasi mas, tidak sayang keluarga terutama istri dan orang tua, dengan ARV lebih kecil untuk enularkan mas, kalau jenuh dan capek tidak mas, saya minum obat ARV tanpa beban mas,, tergantung kesadaran pasien mas, saya anggap minum obat tapi saya umpamakan minum vitamin atau permen mas"(IU 7, 20 Januari 2018).

"Kalau menurut saya dari keluarga mas, karena kebanyakan pasien gak terbuka mas, selain itu dari teman mas, kalau tau HIV pasti menjauh dan pasangan juga bisa mempengaruhi semisal jika pasangan gak tau kalau kita HIV mas, riskio putus obat mas, kalau disimpulkan ya paling besar lingkungan mas, yang buat orang putus obat"(IU 8, 20 Januari 2018).

Berdasarkan penjelasan diatas dapat dismpulkan bahwa pengetahuan komunitas LSL HIV positif terhadap tujuan dan fungsi pengobatan ARV sudah baik yaitu komunitas LSL HIV positif telah mengetahui cara kerja dari obat ARV diantaranya (melumpuhkan virus, menekan dan menghambat per-

${ }^{47}$ Alifa Nasyahta Rosiana.Faktor-Faktor yang Mempengaruhi Loss to Follow Up pada Pasien HIV dengan Terapi ARV di RSUP dr. Kariadi Semarang. (Semarang :Jurnal Media Medika Muda Fakultas Kedokteran Universitas Diponegoro, 2014).h 5. 
kembangan virus), mengurangi risiko penularan ke pasangan. Komunitas LSL HIV positif mengetahui layanan VCT dan CST sangat bervariasi yaitu dari facebook, petugas kesehatan dan spanduk yang dipasang di perempatan jalan raya. Sebagian besar komunitas LSL HIV positif tidak mengetahui jenis ARV yang dikonsumsi, walaupun sudah pernah dijelaskan oleh petugas kesehatan. Terdapat sebagian kecil informan mengetahui jenis ARV dari internet/searching. Jenis layanan CST yang di ketahui komunitas LSL HIV positif selain pengobatan ARV adalah konseling, pemeriksaan darah, rontgent, pemeriksaan CD4. Faktor yang paling dominan menyebabkan komunitas LSL HIV positif putus obat adalah, jenuh, rasa bosan, capek minum obat besar-besar, harus minum obat diwaktu dan jam yang sama, efek samping dari obat dan malas.

\section{Kesimpulan}

Berdasarkan hasil penelitian diatas dapat disimpulkan sebagai berikut:

1. Sebagian besar pendapatan individu dari informan utama yaitu 3 (tiga) juta per bulan, sebagian kecil informan utama tidak memiliki pekerjaan tetap sehingga penghasilan perbulan tidak menentu.

2. Sebagian besar informan utama tidak memiliki jaminan kesehatan, hal ini dikarenakan tidak memiliki KK/KTP serta khawatir status HIV diketahui oleh layanan primer (Puskesmas), mengingat syarat berobat ke rumah sakit menggunakan BPJS harus meminta surat rujukan dari fasilitas kesehatan tingkat pertama (Puskesmas) yang ditunjuk. Biaya pertama kali mulai pengobatan ARV sekitar 200-400 ribu dan komunitas LSL HIV positif masih menganggap berat dengan jumlah biaya tersebut.

3. Informan utama mengetahui informasi layanan VCT dan CST sangat bervariasi yaitu dari facebook, petugas kesehatan dan spanduk yang dipasang di perempatan jalan raya. Informan utama mengetahui jenis ARV dari petugas kesehatan dan internet/searching. Faktor kemungkinan komunitas LSL HIV positif putus obat adalah, jenuh, rasa bosan, ukuran obat sangat besar, efek samping obat, minum obat diwaktu/jam yang sama setiap hari dan rasa malas. Akan tetapi informan utama kembali patuh minum obat karena sakit.

4. Keterampilan petugas kesehatan sudah sangat baik, bahasa yang digunakan oleh petugas halus, ramah, tidak membedakan antar pasien dan petugas. Sebagian kecil informan utama menyatakan penjelasan dari konselor kurang detail, tidak ada perhatian dari petugas, kurang komunikatif serta jawaban yang diberikan konselor tidak sesuai dengan keinginan dari informan utama. 


\section{Daftar Pustaka}

Andersen R. \& J.F. Newman. 2005. Societal and Individual Determinants of Medical Care Utilizationin the United State, The Milbank Quarterly,Vol. 83 No. 4.

Anonim. 2014. ODHA dan Jaminan Kesehatan Nasional (serial online). http://www.odhaberhaksehat.org/2014/odha-dan-jaminan-kesehatan nasional/.(4 Mei 2017).

Bustami. 2011. Penjaminan Mutu Pelayanan Kesehatan dan Akseptabilitasnya. Jakarta. Erlangga.

Dinas Kesehatan Kabupaten Jember. 2017. Pemetaan Kasus HIV/AIDS. Bidang Pencegahan Penyakit dan Kesehatan Lingkungan.

Dinas Kesehatan Propinsi Jawa Timur. 2017. Analisis Situasi HIV di Propinsi Jawa Timur. Bidang Pencegahan Penyakit dan Kesehatan Lingkungan.

Elinda, R., Muhammad, A. 2017. Faktor-Faktor yang Berhubungan dengan Keteraturan Kunjungan Layanan Care Suport and Teratment (CST) pada Pasien Koinfeksi TB-HIV di Balai Kesehatan Paru Wilayah Semarang. Jurnal Ilmu Kesehatan Fakultas Keolahragaan Universitas Negeri Semarang, 2 (1): 105-110.

Fletcher, C.V., dan Kakuda, T.N. 2005. Human Immunodeficiency Virus Infection. New York. McGraw-Hill.

Gibson, R.L \& Mitchell, M.H. 2011. Bimbingan dan Konseling. Yogyakarta: Pustaka Pelajar.

GWL INA. 2016. Laporan Semester Program Penjangkauan LSL. Jakarta.

Ilyas, Y. 2003. Asuransi Kesehatan, Review Utilisasi, Manajemen Klaim dan Fraud. Pusat Kajian Ekonomi Kesehatan FKM UI. Jakarta.

Kementerian Kesehatan RI. 2017. Situasi HIV/AIDS di Indonesia. Jakarta.

KPA Nasional. 2007. Modul PMTS-LKB-SUFA Populasi Kunci. Jakarta.

Krisna S. 2011. Incidence Rate of and Factors Assosiated with Loss to Follow up in A Longitudinal Cohort of Anti-retroviral Treated HIV- Infected Person: an AIDS Clinical Trials Group (ACTG) Longitudinal Linked Randomized Trials (ALLRT) Analysis. Jurnal Kesehatan. Vol.5 Juli 2011.

Lestari, Heni Eka Puji, Zahroh Shaluhiyah dan Argyo Demartoto. 2015. Pengaruh Pengetahuan dan Perceived Behavior Control terhadap Niat Lakilaki yang Berhubungan Seks dengan Laki-laki (LSL) untuk Melakukan VCT di Kabupaten Madiun. (Jurnal Promosi Kesehatan Indonesia Vol. 10 No.1, 2015)

LSM Laskar Kabupaten Jember. 2016. Laporan Penjangkauan LSL Program Dukungan IPF PMTS-LKB-SUFA. Bidang Pendamping Lapangan Komunitas LSL Khusus ODHA Kabupaten Jember.

Nawas. 2003. Keberhasilan Pengobatan TB Paru dan Faktor yang Mempenga- 
ruhinya. J Respi Indo.

Nopiyani, N. M.S., Indrayathi, P. A., Listyowati, R., Suarjana, I. K., Januraga, P. 2014. Akses Jaminan Kesehatan Nasional pada Pekerja Seks Perempuan, Jurnal Kesehatan Masyarakat Nasional. 9 (4): 308-314.

Notoatmodjo.S. 2010. Promosi Kesehatan dan Ilmu Perilaku. Jakarta: PT. Rineka Cipta.

Notoatmodjo, S. 2012. Metodologi Penelitian Kesehatan . Jakarta: PT Rineka Cipta.

Rokhmah. D. 2016. Studi Fenomenologi tentang Homoseksual pada Laki-Laki Seks dengan Laki-Laki di Kabupaten Jember. Disertasi. Fakultas Kesehatan Masyarakat Unair.

Rokhmah, D. 2013. Pengetahuan dan Sikap ODHA (Orang HIV dan AIDS) tentang HIV dan AIDS dan Pencegahanya. Jurnal Ilmu Kesehatan Masyarakat, Vol 9. No.2: 136-146.

Rosiana, Alifa Nasyahta. 2014. Faktor-Faktor yang Mempengaruhi loss to follow up pada Pasien HIV dengan Terapi ARV di Rumah Sakit dr. Kariadi Semarang. Jurnal Media Medika Muda. Semarang: Universitas Diponegoro.

Rumenang, D., Umboh, J., Kandon., G. 2015. Faktor-Faktor yang Berhuungandengan Pemanfaatan Peayanan Kesehatan pada Peserta BPJS Kesehatan di Puskesmas Paniki Bawah Kecamatan Mapengat Kota Manado. JIKM. 5

Sugiharti. 2014. Pemanfaatan Layanan Kesehatan pada Perempuan HIV dan AIDS. Jurnal Kesehatan Masyarakat Vol. 8 No. 1

Sukmah, Mahyudin, Suarnanti. 2013. Faktor- faktor yang Berhubungan dengan Kepatuhan Berobat pada Pasien TB Paru di RSUD Daya Makassar. (Jurnal STIKES Nani Hasanudin Vol. 2 Nomor 5).

Supartiningsih, S. 2017. Kualitas Pelayanan dan Kepuasan Pasien Rumah Sakit: Kasus pada Pasien Rawat Jalan. Jurnal Mediceoticolegal dan Managemen Rumah Sakit, 6 (1): 9-15.

Yeni, T., Ina Debora, R.,L. Rafael, P. 2016. Pemanfaatan Voluntary Counseling and Testing oleh Ibu Rumah Tangga Terinfeksi Human Immunodeficiency Virus. Jurnal Kesehatan Masyarakat 11 (2).

Gunawan, Yudhi Tri. 2016. Hubungan Karakteristik ODHA dengan Kejadian Loss to Follow up Terapi ARV di Kabupaten Jember. Jurnal Kesehatan Masyarakat. Vol. 12. 1 Maret 2016.

Yuniar, Isma dkk. 2017. Pengaruh PMO dan Dukungan Keluarga Terhadap Tingkat Kepatuhan Minum Obat TB Paru di Puskesmas Sempor $1 \mathrm{Ke}-$ bumen. Proceeding $6^{\text {th }}$ University Research Colloqium 2017 : Seri MIPA dan Kesehatan. 